\title{
Induced Defoliation and Corn Productivity Performance
}

\author{
Wellington Junior Candido da Silva ${ }^{1} \&$ Flávio Carlos Dalchiavon ${ }^{1}$ \\ ${ }^{1}$ Department of Agronomy, Federal Institute of Education, Science and Technology of Mato Grosso, Campo \\ Novo do Parecis, MT, Brazil \\ ${ }^{2}$ Brazilian Agricultural Research Corporation, Embrapa Soybean, Londrina, PR, Brazil \\ Correspondence: Flávio Carlos Dalchiavon, Department of Agronomy, Federal Institute of Education, Science \\ and Technology of Mato Grosso, 78360-000, Campo Novo do Parecis, MT, Brazil. Tel: 55-65-99617-5059. \\ E-mail: flavio.dalchiavon@cnp.ifmt.edu.br
}

Received: October 1, 2019

Accepted: November 15, 2019

Online Published: March 15, 2020

doi:10.5539/jas.v12n4p128

URL: https://doi.org/10.5539/jas.v12n4p128

\begin{abstract}
Due to the change in the environment, diseases and insects can reduce the leaf area of agricultural crops. The objective of this study was to determine the impact of induced defoliation on the vegetative and reproductive phases of corn on its agronomic characteristics. The experiment was carried out in the experimental area of the Mato Grosso Federal Institute of Education, Science and Technology, Campo Novo do Parecis campus, in a second crop system in the 2017/2018 agricultural year, with sowing in March. This study used a randomized complete block design, consisting of 24 treatments and three replications, comprising eight phenological stages. The treatments were performed from the fourth leaf stage (V4) to physiological maturation (R5), with defoliation in the lower, middle and upper thirds of the plant. The characteristics evaluated were: plant height, stem diameter, ears insertion height, ears length, ears diameter, ears weight, number of rows per ears, number of grains per row, weight of grain per ears, prolificity; harvest index, weight of one thousand grains and grain yield. Defoliation between the fourth (V4) and twelfth leaves (V12) does not interfere in the evaluated characteristics. Grain and ear weight are interfered when defoliation occurs in the middle and upper third of plants in V12. Defoliation between flowering (R1) and beginning of grain filling (R2) negatively affects the weight of one thousand grains, grain and ear weight, and may reduce grain yield by up to $30 \%$. Defoliation in the upper third of the plant significantly reduces the diameter and length of ears, grain and corn ear of the corn crop.
\end{abstract}

Keywords: leaf area removal, photosynthesis, production components, Zea mays L.

\section{Introduction}

Corn (Zea mays L.) is an important commodity in global nutrition and its yield is dependent on the how a plant allocates the accumulated biomass between the corn grains and other plant parts. The plant's growth, represented by the accumulation of the dry matter depends on photosynthesis, is the process in which photosynthetically active radiation (light) is transformed into chemical energy (Karam et al., 2010).

Corn productive components are defined in the vegetative period, from V4 and V5 (fourth and fifth leaves developed, respectively), where the tassel and ears beginnings to be formed with the differentiation of all the leaves. At V5, the apical meristem develops below ground, which explains that at that stage, the plant can undergo some injury on the aerial part and recover with no significant damage to its production performance, since the number of grain rows per ears is defined at V8 (eighth developed leaf), while the number of grains per row until the V17 stage (Ritchie et al., 1993; Magalhães \& Durães, 2006; Alvim et al., 2010). The real impact on yield caused by stress, whether water or caused by leaf area removal, affects the period from pre-flowering (VT) to grain filling (R2), according to the phenological scale of Ritchie et al. (1993) and Brito et al. (2011).

In corn production, management techniques aligned with the correct use of cultivation tools such as sowing planning, genetic improvement, biotechnology, tillage, plant nutrition, phytosanitary control and planned harvesting, are indispensable to the amount of solar radiation intercepted by the leaves. Without solar radiation, the production would be reduced, because corn is the species of agricultural importance that most expresses its productive potential due to the use of solar radiation (Strieder et al., 2007).

Altering the redistribution of photoassimilates in the plant results in the deficit in the source:sink ratios. These changes are caused by stresses and leaf injuries that result in the imbalance in leaf arrangement, microclimate, 
plant density and, mainly, leaf area. These losses are denominated defoliation, originated by biotic and abiotic factors. In this context, it is essential to detect tolerable defoliation levels in corn as it is a plant that has low compensation index, low prolificity and small leaf plasticity (Pereira et al., 2012).

Biotic defoliation in corn can be caused by pests, while abiotic defoliation can be due to the climate, such as excessive or severe rainfall, winds, frost and hail. Both factors strictly reduce the photosynthetically active leaf area (Torres et al., 2013), which can represent a serious crop damage, depending on which phase the corn plant is.

In the early growth stages, defoliation causes little or no reduction in crop yield (Ritchie et al., 1993; Magalhães \& Durães, 2006); however, as the plant develops, there is a tendency to increase the severity over the mentioned productivity. Therefore, the simulation of damage caused on the leaf area is important to know the source:sink ratios studies, as well as the knowledge of the photoassimilates distribution in the corn plant (Alvim et al., 2010). In addition, studies with corn defoliation are observed at specific phenological stages, predominantly in the vegetative phases, V2 to V20 (Karam et al., 2010; Sangoi et at., 2014; Rezende et al., 2015; Santos et al., 2017), or reproductive stages, R1 to R3 (Alvim et al., 2010; 2011; Pereira et al., 2012; Uitzil et al., 2016; Trogello et al., 2017). The objective of this study was to determine the impact of induced defoliation on the vegetative and reproductive phases of corn on its agronomic characteristics evaluated.

\section{Materials and Methods}

The experiment was conducted in 2018 following a soybean (Glycine max L.) crop, in the experimental area at Mato Grosso Federal Institute of Education, Science and Technology, Campo Novo do Parecis Campus, on a dystrophic Red Latosol, according to the Brazilian Soil Classification System (Empresa Brasileira de Pesquisa Agropecuária [EMBRAPA], 2018). The area was located at the geographic coordinates $13^{\circ} 40^{\prime} 37^{\prime \prime}$ South latitude and $57^{\circ} 47^{\prime} 30^{\prime \prime}$ West longitude and at $574 \mathrm{~m}$ above sea level. The local climate, according to the Köppen classification, is Aw type, tropical climate with well-defined dry season, between May and September (Dallacort et al., 2011). The average maximum, mean and minimum temperatures over the experimental period were 29.4; 22.1 and $17.5^{\circ} \mathrm{C}$, respectively, as well as $416.8 \mathrm{~mm}$ rainfall (Figure 1), which partially met the water demand of the crop, which is between 450 and $800 \mathrm{~mm}$, regularly distributed throughout its growth cycle (Bergamaschi \& Matzenauer, 2014).

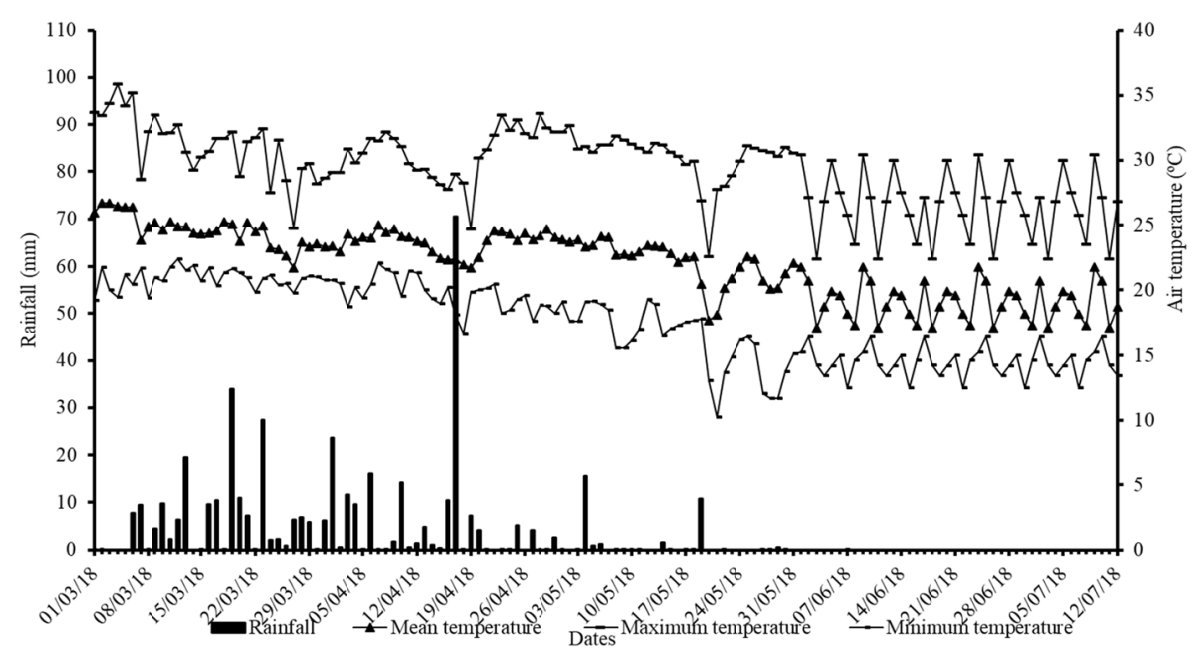

Figure 1. Rainfall and average temperatures over the experimental period, 2018

The experiment used a randomized complete block design with 24 treatments (Table 1) and three replicates based on the phenological scale of Ritchie et al. (1993). 
Table 1. Description of the treatments based on phenological scale of Ritchie et al. (1993)

\begin{tabular}{lll}
\hline Control & T1 & No defoliation \\
\hline V4 & T3 & Defoliation of the two lower leaves \\
Defoliation of the two upper leaves
\end{tabular}

Only photosynthetically active leaves were considered, discarding senescent leaves. The experimental plot consisted of seven rows $7 \mathrm{~m}$ long, 0.45 meters between rows. The sample area of the plot consisted of four rows (third to sixth row) for center $5 \mathrm{~ms}$, eliminating one meter at each end of the research plot.

Following the soybean harvest (March 3, 2018), the area was sprayed with glyphosate $\left(648 \mathrm{~g} \mathrm{~L}^{-1}\right)$ at a dose of 1.5 $\mathrm{L} \mathrm{ha}^{-1}$ (commercial product - c.p.) to kill the existing vegetation. The area was than planted with the corn hybrid DKB 290 VT PRO $^{\circledR}$ at a rate of 2.8 seeds per meter $\left(60,000\right.$ plants ha $\left.{ }^{-1}\right)$ on March, 2018. The corn seed was planted with a seven-row planter.

Fertilization at planting was performed according to soil fertility analysis and crop requirements, 15, 60 and 40 $\mathrm{kg} \mathrm{ha}^{-1}$ of N, $\mathrm{P}_{2} \mathrm{O}_{5}$ and $\mathrm{K}_{2} \mathrm{O}$, respectively. In the first topdressing fertilization (V4), $300 \mathrm{~kg} \mathrm{ha}^{-1}$ of 20-00-20 $\left(\mathrm{N}-\mathrm{P}_{2} \mathrm{O}_{5}-\mathrm{K}_{2} \mathrm{O}\right)$ was applied, followed by $100 \mathrm{~kg} \mathrm{ha}^{-1}$ application (20-00-20) for the second topdressing fertilization (V8) for a projected grain yield of $8 \mathrm{tha}^{-1}$ (Souza \& Lobato, 2004).

After corn emergence, insect monitoring was performed and a moderate infestation of stink bug (Nezara viridula) was found, and was controlled with tiametoxan $\left(250 \mathrm{~g} \mathrm{~kg}^{-1}\right)$ at a dose of $250 \mathrm{~mL} \mathrm{ha}^{-1}$. At the V4 stage, with the objective of controlling Nezara viridula and Diabrotica speciosa, the insecticides bifenthrin $\left(50 \mathrm{~g} \mathrm{~L}^{-1}\right)$ and carbosulfan $\left(150 \mathrm{~g} \mathrm{~L}^{-1}\right)$ was applied at the dose of $0.5 \mathrm{~L}^{-1}$, and thiametoxan $\left(250 \mathrm{~g} \mathrm{~kg}^{-1}\right)$ was applied at a dose of $250 \mathrm{~mL} \mathrm{ha}^{-1}$. At V10, triflumuron $\left(480 \mathrm{~g} \mathrm{~kg}^{-1}\right)$ at a dose of $100 \mathrm{~mL} \mathrm{ha}^{-1}$ was applied to control Spodoptera frugiperda.To control the diseases Helminthosporium turcicum and Cercospora zeae-maydis, epoxiconazole (50 $\left.\mathrm{g} \mathrm{L}^{-1}\right)$ and piraclostrobin $\left(133 \mathrm{~g} \mathrm{~L}^{-1}\right)$ at $0.5 \mathrm{~L}^{-1}$ were applied at $\mathrm{V} 8$, and metconazole $\left(80 \mathrm{~g} \mathrm{~kg}^{-1}\right)$ at the dose of 650 $\mathrm{mL} \mathrm{ha}{ }^{-1}$ was applied at V10. For weed control, glyphosate $\left(648 \mathrm{~g} \mathrm{~L}^{-1}\right)$ was applied (of product per ha) at V2 at a dose of $1.5 \mathrm{~L} \mathrm{ha}^{-1}$ and atrazine $\left(500 \mathrm{~g} \mathrm{~L}^{-1}\right)$ at a dose of $0.5 \mathrm{~L} \mathrm{ha}^{-1}$ in $\mathrm{V} 4$, with application volume (water + product) of $80 \mathrm{~L} \mathrm{ha}^{-1}$, with $60 \mathrm{lbs}$ of pressure.

The vegetative characteristics evaluated in R2 included plant height (PLH, $\mathrm{m}$ ), which was the distance from the ground level to the top of the tassel and the stem diameter (SD, $\mathrm{mm}$ ), measured with a digital caliper at $5 \mathrm{~cm}$ from the ground level. These measurements were collected from ten plants from the research plot. 
The production characteristics were measured on five plants/ears at physiological maturity (R6) were ears insertion height $(\mathrm{EIH}, \mathrm{m})$, which is the distance between soil level and first ears node insertion; ears length (EL, $\mathrm{cm})$; ears diameter $(\mathrm{ED}, \mathrm{mm})$, obtained with digital caliper in its middle third; ears weight (EW, g), with the aid of a digital scale; number of rows per ears (NRE); number of grains per row (NGR); weight of grain per ears (WGE, g); prolificity in 10 plants per plot (PRL); harvest index (HI), obtained by the ratio of the threshed and non- threshed ears weight; weight of one thousand grains (WTG, g), with moisture correction to $13 \%$ (wet basis), as well as to estimate grain yield ( $\left.\mathrm{GY}, \mathrm{kg} \mathrm{ha}^{-1}\right)$ based on the entire plot useful area. The manual harvest was performed on December 7, 2018, where all the ears contained in the useful area of the plot were collected.

Once the assumptions of homogeneity and constant variance of the residues are met by the Levene test, data were submitted to analysis of variance and, when significant $F(p<0.05)$, it was submitted to the Scott-Knott mean test for comparison of treatments through statistical software SISVAR (Ferreira, 2011).

\section{Results and Discussion}

Only the characteristics plant height, weight of one thousand grains, number of grains per ears, ears length, weight of grain per ears, ears weight and harvest index were statistically significant by the $\mathrm{F}$ test $(\mathrm{p}<0.05)$ (Table 2). The coefficients of variation ranged from 2.5 to $12.4 \%$ (Table 2), remaining between low (up to $10 \%$ ) and medium (10-20\%), according to classification of Pimentel and Garcia (2002). The variability of the coefficient of variation is linked to the environment and the agronomic characteristics of corn (Hiolanda et al., 2018).

Table 2. Summary of analysis of variance for vegetative and productive characteristics of corn in second crop (Campo Novo do Parecis, MT, 2018)

\begin{tabular}{|c|c|c|c|}
\hline Characteristics $^{1}$ & $\overline{\mathrm{F}^{2}}$ & $\mathrm{CV}(\%)^{3}$ & $\mathrm{OM}^{4}$ \\
\hline PLH (m) & $2.3^{* *}$ & 2.5 & 2.61 \\
\hline $\mathrm{SD}(\mathrm{cm})$ & 0.9 & 5.8 & 2.22 \\
\hline EIH (m) & 0.9 & 5.4 & 1.34 \\
\hline WTG (g) & $2.1^{*}$ & 8.4 & 331.7 \\
\hline PRL & 0.7 & 7.5 & 1.1 \\
\hline NRE & 0.6 & 3.5 & 17.2 \\
\hline NGE & 1.9 & 6.5 & 549.4 \\
\hline NGR & 1.7 & 6.6 & 31.9 \\
\hline $\mathrm{ED}(\mathrm{cm})$ & 1.5 & 3.6 & 5.12 \\
\hline $\mathrm{EL}(\mathrm{cm})$ & $3.0^{* *}$ & 4.6 & 14.71 \\
\hline WGE (g) & $2.9^{* *}$ & 9.4 & 149.1 \\
\hline EW (g) & $3.7^{* *}$ & 9.5 & 191.4 \\
\hline HI & $2.7^{* *}$ & 3.0 & 0.70 \\
\hline GY $\left(\mathrm{kg} \mathrm{ha}^{-1}\right)$ & 1.3 & 12.4 & 8163 \\
\hline
\end{tabular}

Note. ${ }^{1} \mathrm{PLH}=$ plant height, $\mathrm{SD}=$ stem diameter, $\mathrm{EIH}=$ ears insertion height, $\mathrm{WTG}=$ weight of one thousand grains, $\mathrm{PRL}=$ prolificity, NRE $=$ number of rows per ears, NGE $=$ number of grains per ears, $\mathrm{NGR}=$ number of grains per row, $\mathrm{ED}=$ ears diameter, $\mathrm{EL}=$ ears length, $\mathrm{WGE}=$ weight of the grains per ears, $\mathrm{EW}=$ ears weight, $\mathrm{HI}=$ harvest index, $\mathrm{GY}=$ grain yield; ${ }^{2} * *$ and $*$ significant at 1 and $5 \%$, respectively; ${ }^{3} \mathrm{CV}=$ coefficient of variation; ${ }^{4} \mathrm{OM}=$ overall mean.

The treatments in which defoliation was performed in the first (V4) and last stages (starting at R1), together with the control, were those that prusuced the larger plants (over $2.6 \mathrm{~m}$ ). These results show that leaf damage at the beginning of corn plant development does not produce a decrease plant growth. This indicates that the plant has the ability to recover by the end of the cycle when the plant naturally ceases its growth as the channeling of its energies at this stage is towards the reproductive structures (Table 3). In contrast, when defoliation occurred between V4 and R1, plant plant height was reduced to $2.5 \mathrm{~m}$ or less. Therefore, when the plants are in full structural growth and environmental stress, defoliation can impair the growth process. This trend is consistent with research by Souza et al. (2015), where defoliation between V5 and V8 did not affect plant height, but did adversely affect plant height when the defoliation occurred from VT to R3. 
As the plants evolved in the vegetative phases of development, it was found that the defoliation of the lower third did not influence their height, a fact caused by the lower uptake of sunlight by these leaves in relation to the leaves of the pointer (Table 3). For the reproductive phase, the same behavior was verified, however, it was attributed to the natural senescence of the leaves in this phase of the plant development as well as to the occurrence of leaf diseases (Helminthosporium turcicum and Cercospora zeae-maydis), clearly culminating, in reduction of photosynthetic capacity. Such findings were also reported by Gaias et al. (2017), where the highest plant height was shown in the control, then it decreased from V4 or when the leaf removal occurred in the middle and upper third. Additionally, Rezende et al. (2015) found that the greater the leaf removal, the smaller the plant height and, consequently, the ears insertion height.

For stem diameter, whose average values ranged from 2.1 to $2.4 \mathrm{~cm}$, no significant difference was found between treatments (Tables 2 and 3) as it was also found by Vaz et al. (2016) and Gaias et al. (2017). According to Sangoi et al. (2012), the stem has a vital function in plant support when subjected to stresses on the leaf area, caused by pests, physiological disturbances, climate, hail and wind, being a source of carbohydrate supply to compensate the plant balance.

Ears insertion height, with averages between 1.2 and $1.4 \mathrm{~m}$, showed no effect of defoliation levels (Tables 2 and 3 ); however, the behavior trend was similar to that of plant height. The lack of significant results for this characteristic in relation to defoliation levels may be justified by the fact that the new cultivars are formed through breeding programs that target more compact plants, thereby increasing the balance, reducing the lodging and enhancing the efficiency of mechanized harvest (Souza et al., 2015).

Regarding prolificity, no significant difference was observed between treatments (Tables 2 and 3), corroborating Alvim et al. (2010) and Trogello et al. (2017) who found that prolificity is negatively affected only when a complete leaf removal is performed. Tinca et al. (2015) pointed out that prolificity is intrinsically related to genotypic factors previously determined in their genetic improvement, however, adequate management and edaphoclimatic conditions may indirectly interfere with this trait.

Table 3. Mean values for plant height (PLH), stem diameter (SD), ear insertion height (EIH) and prolificity (PRL) of corn grown in the second harvest (Campo Novo do Parecis, MT, 2018)

\begin{tabular}{|c|c|c|c|c|c|}
\hline Phenological stage & Treatments & PLH (m) & $\mathrm{SD}(\mathrm{cm})$ & EIH $(m)$ & PRL \\
\hline & $\mathrm{T} 1$ & $2.60 \mathrm{~b}$ & 2.20 & 1.35 & 1.1 \\
\hline \multirow{2}{*}{ V4 } & $\mathrm{T} 2$ & $2.61 \mathrm{a}$ & 2.26 & 1.36 & 1.2 \\
\hline & $\mathrm{T} 3$ & $2.52 \mathrm{~b}$ & 2.26 & 1.33 & 1.2 \\
\hline \multirow{3}{*}{ V8 } & $\mathrm{T} 4$ & $2.65 \mathrm{a}$ & 2.27 & 1.38 & 1.2 \\
\hline & $\mathrm{T} 5$ & $2.57 \mathrm{~b}$ & 2.12 & 1.29 & 1.1 \\
\hline & $\mathrm{T} 6$ & $2.57 \mathrm{~b}$ & 2.18 & 1.25 & 1.1 \\
\hline \multirow{3}{*}{ V12 } & $\mathrm{T} 7$ & $2.62 \mathrm{a}$ & 2.23 & 1.33 & 1.1 \\
\hline & $\mathrm{T} 8$ & $2.57 \mathrm{~b}$ & 2.14 & 1.32 & 1.1 \\
\hline & T9 & $2.47 \mathrm{~b}$ & 2.40 & 1.29 & 1.2 \\
\hline \multirow{3}{*}{ R1 } & $\mathrm{T} 10$ & $2.57 \mathrm{~b}$ & 2.22 & 1.34 & 1.1 \\
\hline & $\mathrm{T} 11$ & $2.66 \mathrm{a}$ & 2.26 & 1.40 & 1.2 \\
\hline & $\mathrm{T} 12$ & $2.63 \mathrm{a}$ & 2.36 & 1.34 & 1.2 \\
\hline \multirow{3}{*}{$\mathrm{R} 2$} & $\mathrm{~T} 13$ & $2.60 \mathrm{~b}$ & 2.33 & 1.32 & 1.1 \\
\hline & $\mathrm{T} 14$ & $2.58 \mathrm{~b}$ & 2.11 & 1.33 & 1.1 \\
\hline & $\mathrm{T} 15$ & $2.63 a$ & 2.14 & 1.35 & 1,1 \\
\hline \multirow{3}{*}{ R3 } & T16 & $2.63 \mathrm{a}$ & 2.33 & 1.37 & 1.1 \\
\hline & $\mathrm{T} 17$ & $2.70 \mathrm{a}$ & 2.34 & 1.38 & 1.2 \\
\hline & $\mathrm{T} 18$ & $2.68 \mathrm{a}$ & 2.20 & 1.36 & 1.2 \\
\hline \multirow{3}{*}{ R4 } & T19 & $2.52 \mathrm{~b}$ & 2.22 & 1.33 & 1.1 \\
\hline & T20 & $2.63 \mathrm{a}$ & 2.23 & 1.34 & 1.1 \\
\hline & $\mathrm{T} 21$ & $2.69 \mathrm{a}$ & 2.26 & 1.42 & 1.1 \\
\hline \multirow{3}{*}{ R5 } & T22 & $2.70 \mathrm{a}$ & 2.26 & 1.39 & 1.1 \\
\hline & T23 & $2.57 \mathrm{~b}$ & 2.27 & 1.28 & 1.1 \\
\hline & $\mathrm{T} 24$ & $2.70 \mathrm{a}$ & 2.24 & 1.41 & 1.1 \\
\hline
\end{tabular}

Note. Distinct letters are different from each other by the test of Scott-Knott, at 5\% probability; $\mathrm{T} 1=$ control. 
The weight of one thousand grains achieved the greatest values (332.1 to $369.7 \mathrm{~g}$ ) when defoliation was performed at V4, V8, V12, R4 and R5 (Table 4), while the minors grains (297.1 to $325.9 \mathrm{~g}$ ), which showed the greatest effects of defoliation, were plants whose leaves removed between R1 and R3. Consequently, this behavior reflected directly on the weight grain per ear and ears weight (Table 5). So, a critical period (R1 to R3) was observed in corn crop in relation to loss of leaf area and its effects on plant reproductive characteristics, which was also evidenced by Trogello et al. (2017), when they observed that in stage R1, as defoliation intensity increased, there was a reduction in the weight of one thousand grains, grain weight per ear and ear weight. Additionally, Alvim et al. (2010) reported that the weight of one thousand grains is intrinsically related to the source and drainage capacity of the plant, where defoliation from R3 no longer influences this characteristic, since the grains have their photoassimilates guaranteed for their complete formation and filling.

Regarding the number of rows per ears, number of grains per ear and number of grains per row, no significant differences were detected between treatments (Tables 2 and 4). Souza et al. (2015) evaluated nine defoliation levels in three different hybrids in the 2010/2011 crop and did not obtain any statistical significance for the number of rows per ears and number of grains per row. Alvim et al. (2010) found that defoliation at R2 did not negatively affect the number of grains per row and the number of grains per ear as at this stage, these production components are already defined. Both studies ratify the data of this study.

Table 4. Mean values for weight of one thousand grains (WTG), number of rows per ear (NRE), number of grains per ear (NGE), number of grains per row (NGR) and ear diameter (ED) of corn grown in second crop (Campo Novo do Parecis, MT, 2018)

\begin{tabular}{|c|c|c|c|c|c|c|}
\hline Phenological stage & Treatments & WTG (g) & NRE & NGE & NGR & $\mathrm{ED}(\mathrm{cm})$ \\
\hline & T1 & $300.2 \mathrm{~b}$ & 17 & 571 & 33 & 5.19 \\
\hline \multirow{2}{*}{ V4 } & $\mathrm{T} 2$ & $356.8 \mathrm{a}$ & 17 & 564 & 32 & 5.32 \\
\hline & $\mathrm{T} 3$ & $319.8 \mathrm{~b}$ & 17 & 591 & 34 & 5.15 \\
\hline \multirow{3}{*}{ V8 } & $\mathrm{T} 4$ & $369.7 \mathrm{a}$ & 17 & 523 & 32 & 5.14 \\
\hline & T5 & $305.0 \mathrm{~b}$ & 17 & 545 & 32 & 5.09 \\
\hline & T6 & $366.0 \mathrm{a}$ & 17 & 531 & 31 & 5.19 \\
\hline \multirow{3}{*}{ V12 } & $\mathrm{T} 7$ & $304.7 \mathrm{~b}$ & 17 & 564 & 33 & 5.16 \\
\hline & $\mathrm{T} 8$ & $343.3 \mathrm{a}$ & 17 & 512 & 30 & 5.08 \\
\hline & T9 & $339.3 \mathrm{a}$ & 17 & 519 & 30 & 5.08 \\
\hline \multirow{3}{*}{ R1 } & T10 & $301.5 \mathrm{~b}$ & 17 & 553 & 32 & 4.77 \\
\hline & T11 & $311.5 \mathrm{~b}$ & 17 & 559 & 32 & 5.16 \\
\hline & $\mathrm{T} 12$ & $311.8 \mathrm{~b}$ & 18 & 534 & 30 & 4.94 \\
\hline \multirow{3}{*}{$\mathrm{R} 2$} & T13 & $325.9 \mathrm{~b}$ & 17 & 605 & 35 & 5.17 \\
\hline & T14 & $313.2 \mathrm{~b}$ & 17 & 556 & 33 & 5.05 \\
\hline & $\mathrm{T} 15$ & $314.1 \mathrm{~b}$ & 17 & 467 & 28 & 4.83 \\
\hline \multirow{3}{*}{ R3 } & T16 & $350.4 \mathrm{a}$ & 17 & 551 & 33 & 5.20 \\
\hline & T17 & $297.1 \mathrm{~b}$ & 17 & 558 & 32 & 5.14 \\
\hline & $\mathrm{T} 18$ & $344.6 \mathrm{a}$ & 17 & 532 & 31 & 4.98 \\
\hline \multirow{3}{*}{ R4 } & T19 & $365.3 \mathrm{a}$ & 18 & 591 & 34 & 5.33 \\
\hline & T20 & $334.2 \mathrm{a}$ & 17 & 549 & 31 & 5.21 \\
\hline & $\mathrm{T} 21$ & $338.8 \mathrm{a}$ & 17 & 546 & 32 & 5.16 \\
\hline \multirow{3}{*}{ R5 } & $\mathrm{T} 22$ & $366.4 \mathrm{a}$ & 17 & 541 & 31 & 5.11 \\
\hline & $\mathrm{T} 23$ & $332.1 \mathrm{a}$ & 17 & 577 & 34 & 5.24 \\
\hline & $\mathrm{T} 24$ & $349.3 \mathrm{a}$ & 17 & 548 & 32 & 5.16 \\
\hline
\end{tabular}

Note. Distinct letters differ from each other by the test of Scott-Knott, at 5\% probability; $\mathrm{T} 1=$ control.

Regarding ears diameter, there was no significant difference between treatments (Table 4) although Alvim et al. (2010) found that when the leaves are removed in the upper third of the plants in reproductive stages, the photosynthetic activity is dramatically reduced, leading to a decline in carbohydrate accumulation, which may interfere with production components, grain yield and ears diameter. 
For ears length, no significant difference was found between defoliation levels and control (Tables 2 and 5). However, when defoliation occurs in the upper third of the plant in R1 $(13.8 \mathrm{~cm})$ and R2 $(12.6 \mathrm{~cm})$, the observed responses were similar to the lowest averages showed by Pereira et al. (2012), when the $80 \%$ reduction in leaf area occurred in tasseling. Souza et al. (2015) explained this fact as a reflection of leaf stress affecting the source and drain relationship, where the photoassimilates are transported to larger structures, the ears. Therefore, the definition of its size is influenced from flowering.

Regarding the grain weight per ears, two distinct groupings of means were formed. The group with the highest mean values ranged from 149.8 to $177.8 \mathrm{~g}$ (Table 5), with an overall mean of $158.3 \mathrm{~g}$. The composition of the lowest mean values ranged from 115.0 to $145.1 \mathrm{~g}$ (136.4 g average). Thus, it was found that there was an average reduction of $14 \%$ in weight grain per ears for the group with the lowest means. The highest value $(177.8 \mathrm{~g})$ was found when defoliation occurred in the upper third of plants in R3 and the lowest average (115.0 g) in R2, with defoliation performed in the upper third.

The group with the highest means for the weight grain per ears was formed by the control, for the defoliation at $\mathrm{V} 4, \mathrm{~V} 8, \mathrm{~V} 12, \mathrm{R} 4$ and R5, regardless of the defoliation location in the plant, while the second group, composed by the lowest averages, contemplated the treatments with defoliation from R1 to R3. Thus, it is found that defoliation in flowering and grain filling can drastically affect weight grain, regardless of the defoliation site (Table 5). Souza et al. (2015) found that vegetative and reproductive defoliation reduced weight grain per ears by up to $50 \%$ and that environmental conditions and genotype characteristics can determine yield levels for weight grain per ears.

The effect of defoliation on ear weight can be evidenced in two value classes (Table 5). In the first, with the highest means, the values ranged from 191.0 to $230.1 \mathrm{~g}$ (average of $204.4 \mathrm{~g}$ ), which was formed by defoliation at the beginning of the vegetative period (V4 to V8), besides the control, and in the end of the crop cycle (R3 to R5), in the middle and lower third of the plant, since this region presents leaves with low or no photosynthetic activity, due to self-shading. The second group, with the lowest averages, presented values between 158.8 and $176.3 \mathrm{~g}$ and an average of $169.9 \mathrm{~g}$, when defoliation occurred in V12 (middle and upper third), R1, R2 (middle and upper third) and in R3, with defoliation in the upper third. This group presented a reduction by $17 \%$ in ears weight when compared to the mean of the group with the highest values. Brito et al. (2011) found that the total defoliation of the plant in R2 reduces the ear weight by $56 \%$ and that a significant difference was found at that time with the control when defoliation was performed in any part of the plant. 
Table 5. Average values for ear length (EL), weight of grain per ear (WGE), ear weight (EW), harvest index (HI) and grain yield (GY) of corn grown in the second crop (Campo Novo do Parecis, MT, 2018)

\begin{tabular}{|c|c|c|c|c|c|c|}
\hline Phenological stage & Treatments & $\mathrm{EL}(\mathrm{cm})$ & WGE (g) & EW (g) & HI & GY $\left(\mathrm{kg} \mathrm{ha}^{-1}\right)$ \\
\hline & $\mathrm{T} 1$ & 14.76 & $152.8 \mathrm{a}$ & $194.0 \mathrm{a}$ & $0.79 \mathrm{a}$ & $8,472.6$ \\
\hline \multirow{2}{*}{ V4 } & $\mathrm{T} 2$ & 15.09 & $166.3 \mathrm{a}$ & $209.4 \mathrm{a}$ & $0.79 \mathrm{a}$ & $8,966.0$ \\
\hline & $\mathrm{T} 3$ & 15.11 & $157.3 \mathrm{a}$ & $203.4 \mathrm{a}$ & $0.77 \mathrm{~b}$ & $8,775.2$ \\
\hline \multirow{3}{*}{ V8 } & $\mathrm{T} 4$ & 15.90 & $157.8 \mathrm{a}$ & $207.2 \mathrm{a}$ & $0.76 \mathrm{~b}$ & $7,954.0$ \\
\hline & T5 & 14.46 & $133.2 \mathrm{~b}$ & $176.3 \mathrm{~b}$ & $0.76 \mathrm{~b}$ & $7,389.0$ \\
\hline & T6 & 14.54 & $153.0 \mathrm{a}$ & $199.5 \mathrm{a}$ & $0.77 \mathrm{~b}$ & $9,621.0$ \\
\hline \multirow{3}{*}{ V12 } & $\mathrm{T} 7$ & 14.87 & $151.0 \mathrm{a}$ & $191.0 \mathrm{a}$ & $0.80 \mathrm{a}$ & $8,338.4$ \\
\hline & $\mathrm{T} 8$ & 14.13 & $140.1 \mathrm{~b}$ & $166.5 \mathrm{~b}$ & $0.84 \mathrm{a}$ & $7,516.7$ \\
\hline & T9 & 14.10 & $140.7 \mathrm{~b}$ & $172.4 \mathrm{~b}$ & $0.82 \mathrm{a}$ & $7,669.0$ \\
\hline \multirow{3}{*}{$\mathrm{R} 1$} & $\mathrm{~T} 10$ & 14.51 & $144.3 \mathrm{~b}$ & $184.0 \mathrm{~b}$ & $0.79 \mathrm{a}$ & $8,214.3$ \\
\hline & $\mathrm{T} 11$ & 14.64 & $145.1 \mathrm{~b}$ & $182.0 \mathrm{~b}$ & $0.80 \mathrm{a}$ & $7,832.4$ \\
\hline & $\mathrm{T} 12$ & 13.76 & $129.0 \mathrm{~b}$ & $158.8 \mathrm{~b}$ & $0.81 \mathrm{a}$ & $6,947.3$ \\
\hline \multirow{3}{*}{$\mathrm{R} 2$} & $\mathrm{~T} 13$ & 15.50 & $161.6 \mathrm{a}$ & $210.0 \mathrm{a}$ & $0.77 \mathrm{~b}$ & $7,540.3$ \\
\hline & $\mathrm{T} 14$ & 14.50 & $137.0 \mathrm{~b}$ & $174.0 \mathrm{~b}$ & $0.79 \mathrm{a}$ & $8,012.6$ \\
\hline & $\mathrm{T} 15$ & 12.64 & $115.0 \mathrm{~b}$ & $144.0 \mathrm{~b}$ & $0.80 \mathrm{a}$ & $6,804.8$ \\
\hline \multirow{3}{*}{ R3 } & $\mathrm{T} 16$ & 15.20 & $164.4 \mathrm{a}$ & $216.0 \mathrm{a}$ & $0.76 \mathrm{~b}$ & $8,842.0$ \\
\hline & $\mathrm{T} 17$ & 14.62 & $142.3 \mathrm{~b}$ & $189.3 \mathrm{a}$ & $0.75 \mathrm{~b}$ & $7,933.2$ \\
\hline & $\mathrm{T} 18$ & 14.47 & $137.2 \mathrm{~b}$ & $171.5 \mathrm{~b}$ & $0.80 \mathrm{a}$ & $7,612.7$ \\
\hline \multirow{3}{*}{$\mathrm{R} 4$} & $\mathrm{~T} 19$ & 16.02 & $177.8 \mathrm{a}$ & $230.1 \mathrm{a}$ & $0.77 \mathrm{~b}$ & $8,851.5$ \\
\hline & $\mathrm{T} 20$ & 14.33 & $149.8 \mathrm{a}$ & $195.6 \mathrm{a}$ & $0.77 \mathrm{~b}$ & $7,982.0$ \\
\hline & $\mathrm{T} 21$ & 15.00 & $155.8 \mathrm{a}$ & $201.0 \mathrm{a}$ & $0.77 \mathrm{~b}$ & $8,660.2$ \\
\hline \multirow{3}{*}{ R5 } & $\mathrm{T} 22$ & 15.05 & $158.8 \mathrm{a}$ & $209.4 \mathrm{a}$ & $0.76 \mathrm{~b}$ & $8,499,6$ \\
\hline & $\mathrm{T} 23$ & 15.28 & $163.8 \mathrm{a}$ & $214.1 \mathrm{a}$ & $0.77 \mathrm{~b}$ & $8,696.1$ \\
\hline & $\mathrm{T} 24$ & 14.70 & $146.2 \mathrm{a}$ & $197.0 \mathrm{a}$ & $0.75 \mathrm{~b}$ & $8,782.7$ \\
\hline
\end{tabular}

Note. Distinct letter differ from each other by the test of Scott-Knott, at 5\% probability; T1 = control.

Regarding the harvest index (HI), it was also possible to highlight two distinct groups, one with a value greater than 0.79 (mean of 0.80 ) and another with values less than 0.77 (mean of 0.75 ), according to Table 5. Overall, the absence of defoliation (control), or defoliation up to R2 had lower, albeit significant, effects on this characteristic, whereas defoliation from R3 reflected in lower harvest index. Karam et al. (2010) also observed that there was no statistical difference for defoliation performed between V2 and V4. According to Sangoi (2001), the variations in the harvest index that occur in corn are designated by the characteristics of each genotype, related to the photoassimilates translocation from the leaves to the grain. Besides, this characteristic is strictly linked to the photosynthetic capacity of the leaves, leaf longevity, the source-drain relationship, especially stem-to-grain translocation, the need for other structures of the plant in the reproductive phase and the size and ear formation as a drain.

Grain yield (GY) showed no significant difference between the treatments under study (Tables 2 and 5). Nevertheless, it was observed that when defoliation occurred in the upper third of the plant at R2 (T15), a reduction by $30 \%$ was observed in grain yield compared to the treatment with the highest grain yield, $9621.0 \mathrm{~kg}$ $\mathrm{ha}^{-1}$ (T6). Such phase (R2) was also reported to be the most sensitive to defoliation (with major negative effects on grain yield) by Brito et al. (2011) and Vaz et al. (2016). On the other hand, Gaias et al. (2017) also found that defoliation in the vegetative period, especially in V4, is not different from the control (absence of defoliation).

Even when subjected to adverse conditions that damage the leaf tissue, the corn agronomic characteristics may have different behaviors, depending on the hybrid performance, climatic conditions, nutritional status and plant phenological stage (Pereira et al., 2012; Sangoi et al., 2014). Souza et al. (2015) found in an experiment conducted for two years, that the influence of the environment is relevant to the performance of the defoliated hybrids, since in the first year there was a reduction of approximately $56 \%$ in grain yield, while in the second year the reduction was $80 \%$. 
The results obtained in this research show the importance of adopting a productive management for high technological corn, where the genotypic characteristics of the crop can play their potential, offsetting the adversities that may damage its leaf area.

\section{Conclusions}

Defoliation between the fourth (V4) and twelfth leaves (V12) does not interfere in the evaluated characteristics, except for grain and ears weight when defoliation occurs in the middle and upper third of plants in V12. Defoliation between flowering (R1) and beginning of grain filling (R2) negatively affects the weight of one thousand grains, grain and ear weight, and can reduce grain yield by up to $30 \%$. Defoliation in the upper third of the plant significantly reduces the ear diameters and lengths, and the grain and ear weight of the corn crop.

\section{Acknowledgements}

The authors would like to thank the Research Group in Phytotechny (GPF) of the Federal Institute of Education, Science and Technology of Mato Grosso (IFMT)-Campus Campo Novo do Parecis, for its help and funding.

\section{References}

Alvim, K. R. T., Brito, C. H., Brandão, A. M., Gomes, L. S., \& Lopes, M. T. G. (2010). Quantificação da área foliar e efeito da desfolha em componentes de produção de milho. Ciência Rural, 40(5), 1017-1022. https://doi.org/10.1590/S0103-84782010000500003

Alvim, K. R. T., Brito, C. H., Brandão, A. M., Gomes, L. S., \& Lopes, M. T. G. (2011). Redução da área foliar em plantas de milho na fase reprodutiva. Revista Ceres, 58(4), 413-418. https://doi.org/10.1590/ S0034-737X2011000400002

Bergamaschi, H., \& Matzenauer, R. (2014). O milho e o clima (1st ed., p. 85). Porto Alegre: Emater/RS-Ascar.

Brito, C. H., Silveira, D. L., Brandão, A. M., Gomes, L. S., \& Lopes, M. T. G. (2011). Redução de área foliar em milho em região tropical no Brasil e os efeitos em caracteres agronômicos. Interciencia, 36(4), 291-295.

Dallacort, R., Martins, J. A., Inoue, M. H., Freitas, P. S. L., \& Coletti, A. J. (2011). Distribuição das chuvas no município de Tangará da Serra, médio norte do Estado de Mato Grosso, Brasil. Acta Scientiarum Agronomy, 33(2), 193-200.

EMBRAPA (Empresa Brasileira de Pesquisa Agropecuária). (2018). Sistema brasileiro de classificação de solos (5th ed., p. 590). Brasília, DF: Embrapa.

Ferreira, D. F. (2011). Sisvar: A computer statistical analysis system. Ciência e Agrotecnologia, 35(6), 1039-1042.

Gaias, W. L., Gibbert, E. R., Chidichima, L. P. S., Hendges, C., \& Muller, A. L. (2017). Corn Crop Performance in Different Levels of Defoliation. Journal of Agricultural Science, 10(1), 354-354. https://doi.org/10.5539/ jas.v10n1p354

Hiolanda, R., Machado, D. H., Candido, W. J., Faria, L. C., \& Dalchiavon, F. C. (2018). Desempenho de genótipos de feijão carioca no Cerrado Central do Brasil. Revista de Ciências Agrárias, 41(3), 815-824. https://doi.org/10.19084/rca17285

Karam, D., Filho, I. A. P., Magalhães, P. C., Paes, M. C. D., Silva, J. A. A., \& Gama, J. C. M. (2010). Resposta de Plantas de Milho à Simulação de Danos Mecânicos. Revista Brasileira de Milho e Sorgo, 9(2), 201-211. https://doi.org/10.18512/1980-6477/rbms.v9n2p201-211

Magalhães, P. C., \& Durães, F. O. M. (2006). Fisiologia da produção de milho (Circular Técnica 76, p. 10). Sete Lagoas: Embrapa Milho e Sorgo.

Pereira, M. J. R., Bonan, E. C. B., Garcia, A., Vasconcelos, R. L., Gíacomo, K. S., \& Lima, M. F. (2012). Características morfoagronômicas do milho submetido a diferentes níveis de desfolha manual. Revista Ceres, 59(2), 200-205. https://doi.org/10.1590/S0034-737X2012000200008

Pimentel, G. F. P., \& Garcia, C. H. (2002). Estatística aplicada a experimentos agronômicos e florestais (p. 309). Piracicaba: FEALQ.

Rezende, W. S., Brito, C. H., Brandão, A. M., Franco, C. J. F., Ferreira, M. V., \& Ferreira, A. S. (2015). Desenvolvimento e produtividade de grãos de milho submetido a níveis de desfolha. Pesquisa Agropecuária Brasileira, 50(3), 203-209. https://doi.org/10.1590/s0100-204×2015000300003

Ritchie, S. W., Hanway, J. J., \& Benson, G. O. (1993). How a corn plant develops (Special report, 48, p. 26). Ames: Iowa State University of Science and Technology. 
Sangoi, L. (2001). Understanding plant density effects on maize growth and development: An important issue to maximize grain yield. Ciência Rural, 31(1), 159-168. https://doi.org/10.1590/s0103-84782001000100027

Sangoi, L., Picoli Junior, J. G., Vargas, V. P., Vieira, J., Schimitt, A., Zoldan, S. R., Siega, E., \& Carniel, G. (2014). Cobertura nitrogenada como estratégia para reduzir os prejuízos da desfolha em diferentes estádios fenológicos de milho. Semina: Ciências Agrárias, 35(2), 671-682. https://doi.org/10.5433/1679-0359. 2014v35n2p671

Sangoi, L., Schmitt, A., Silva, P. R. F., Vargas, V. P., Zoldan, S. R., Vieira, J., Souza, C. A., \& Bianchet, P. (2012). Perfilhamento como característica mitigadora dos prejuízos ocasionados ao milho pela desfolha do colmo principal. Pesquisa Agropecuária Brasileira, 47(11), 1605-1612. https://doi.org/10.1590/S0100-204X201 2001100007

Santos, O. F., Lima, S. F., Paiva Neto, V. B., Piati, G. L., Osório, C. R. W. S., \& Souza, H. M. (2017). Defoliation of sweet corn plants under irrigation depths and its impact on gas exchange. Revista Brasileira de Engenharia Agrícola e Ambiental, 21(12), 822-827. https://doi.org/10.1590/1807-1929/agriambi.v21n12 p822-827

Souza, D. M. G., \& Lobato, E. (2004). Cerrado: Correção do solo e adubação (2nd ed., p. 295). Brasília: Embrapa Cerrados.

Souza, V. Q., Carvalho, I. R., Follmann, D. N., Nardino, M., Bellé, R., Baretta, D., \& Schmidt, D. (2015). Desfolhamento artificial e seus efeitos nos caracteres morfológicos e produtivos em híbridos de milho. Revista Brasileira de Milho e Sorgo, 14(1), 61-74. https://doi.org/10.18512/1980-6477/rbms.v14n1p61-74

Strieder, M. L., Silva, P. R. F. da, Argenta, G., Rambo, L., Sangoi, L., Silva, A. A. da, \& Endrigo, P. C. (2007). A resposta do milho irrigado ao espaçamento entrelinhas depende do híbrido e da densidade de plantas. Ciência Rural, 37(3), 634-642. https://doi.org/10.1590/S0103-84782007000300006

Tinca, E., Haş, I., \& Copândean, A. (2015). Prolificacy study of maize (Zea mays L.) inbred lines and hybrids on ARDS-Turda. Bulletin of the University of Agricultural Sciences \& Veterinary Medicine Cluj-Napoca. Agriculture, 72(2).

Torres, A. B. A., Oliveira, N. C., Oliveira Neto, A. M., \& Guerreiro, J. C. (2013). Injurias causadas pelo ataque dos percevejos marrom e barriga verde durante o desenvolvimento inicial do milho. Journal of Agronomic Sciences, 2(2), 169-177.

Trogello, E., Borges, L. F., Oliveira, F. A., Mutaguti, Q. S., Barros, I. G., \& Modolo, A. J. (2017). Respostas morfoagronômicas de milho submetido a desfolha artificial. Revista Brasileira de Milho e Sorgo, 16(3), 460-468. https://doi.org/10.18512/1980-6477/rbms.v16n3p460-468.

Uitzil, A. M. P., Souza, V. Q., Olivoto, T., Nardino, M., Carvalho, I. R., Ferrari, M., ... Demari, G. H. (2016). Yield components of hybrid based on the plant population and artificial defoliation. Australian Journal of Basic and Applied Sciences, 10(10), 136-142.

Vaz, P. F. T., Simonetti, A. P. M. M., \& Montiel, C. B. (2016). Efeito da desfolha de plantas de milho sobre parâmetros produtivos. Acta Iguazu, 5(2), 94-101.

\section{Copyrights}

Copyright for this article is retained by the author(s), with first publication rights granted to the journal.

This is an open-access article distributed under the terms and conditions of the Creative Commons Attribution license (http://creativecommons.org/licenses/by/4.0/). 